\title{
LITERASI INFORMASI TENTANG KEMASAN PRODUK OBAT BEBAS
}

\author{
Cahya Purnama Dini dan Puji Lestari \\ Program Studi Ilmu Komunikasi FISIP Universitas Pembangunan Nasional “Veteran” \\ Yogyakarta Jl. Babarsari 2 Yogyakarta 55281(Kampus Unit II), Telp. +62 274 486733, \\ Email: pujilestariginting@yahoo.co.id
}

\begin{abstract}
This study aims to determine the motive of the public to read or understand the information contained on the drug packaging OTC, identify the ability of people to understand information on the the drug packaging OTC and the utilization of existing information. This is a qualitative research. Researchers collected data in the Kepuharjo village, Cangkringan, Sleman, Yogyakarta. The result shows that the main reason of people reading the instructions on the drug packaging OTC is to be safe after consuming drugs. However, other clue, such as drug side effects is less noticed. Because of consuming drugs is always safe, it makes people repeat in consuming drugs considered suitable for her. People do this in accordance with rules of consuming drugs because they expect to get speedy recovery. The other reason is to make as information or knowledge when they will consume drugs.
\end{abstract}

Key words: Information medicinal product packaging, medication use, health.

\begin{abstract}
Abstrak
Penulisan ini bertujuan mengetahui motif masyarakat dalam membaca atau memahami informasi pada kemasan obat yang dijual bebas, mengidentifikasi kemampuan masyarakat dalam memahami informasi pada kemasan obat yang dijual bebas dan mengetahui pemanfaatan informasi pada kemasan obat yang dijual bebas di wilayah Kepuharjo Kecamatan Cangkringan Kabupaten Sleman Daerah Istimewa Yogyakarta. Hasil penelitian menunjukkan alasan utama masyarakat selalu membaca petunjuk pada kemasan obat yang dijual bebas ialah supaya aman setelah mengkonsumsi obat tersebut, khususnya masa berlaku obat. Petunjuk lain misalnya, efek samping obat kurang diperhatikan. Karena setiap mengkonsumsi obat selalu aman, menjadikan masyarakat untuk selalu mengulangi obat yang dianggap cocok. Masyarakat mengkonsumsi obat sesuai aturan penggunaan. Harapannya supaya cepat sembuh. Alasan yang lain ialah menjadikan informasi atau ilmu sebagai pengetahuan apabila akan mengkonsumsi obat.
\end{abstract}

Kata Kunci: Informasi kemasan produk obat, penggunaan obat, kesehatan.

\section{Pendahuluan}

Dengan melihat keadaan ekonomi saat ini, tampaknya masyarakat harus menyikapinya dengan tepat, salah satunya adalah pola hidup ekonomis atau hidup secara hemat. Strategi saat ini paling sederhana adalah melakukan penghematan dapat dilakukan dalam segala bidang, termasuk di bidang kesehatan. Kesehatan mahal harganya, adalah ungkapan yang sering terdengar di masyarakat. Hal ini terbukti dengan makin banyaknya masyarakat. Untuk mengeluarkan biaya jasa dokter khususnya dokter spesialis masih belum terjangkau oleh sebagian masyarakat.
Belum lagi harga obat yang cukup mahal dan harganya pasti akan semakin mahal. Ditambah lagi dengan beban biaya pemeriksaan laboratorium, pemeriksaan radiologis, pemeriksaan patologis dan pemeriksaan penunjang lainnya akan semakin tidak terjangkau.

Biaya akan semakin tinggi apabila pasien divonis menjalani rawat inap atau operasi. Hal tersebut yang terjadi di masyarakat saat ini. Biaya pelayanan kesehatan saat ini dinilai terlalu mahal dan banyak perbedaan antara satu rumah sakit dengan rumah sakit lain dengan kualitas dan jenis pelayanan yang sama. Lemahnya sistem pengelolaan keuangan 
khususnya Rumah Sakit Pemerintah milik Depkes atau Pemda, sementara persaingan rumah sakit terus meningkat dari segi teknologi maupun sumber daya menimbulkan kecenderungan Rumah Sakit untuk membeli alat canggih untuk memudahkan diagnosis, hal ini akan menyebabkan meningkatkan pembiayaan yang harus di keluarkan oleh pasien dalam menerima pelayanan yang di berikan, karena pembiayaan alat tersebut akan di bebankan kepada pasien (Cost Containment Program) dalam (Depkes : http://depkes.go.id/index. php? option $=$ news $\&$ task $=$ viewarticle $\&$ sid $=1522$ $\&$ itemid $=2: 3 / 14 / 2007$ ) (diakses tanggal 19 April 2009, 1. 01 PM).

Kesehatan yang semakin hari semakin mahal membuat resah masyarakat yang tingkat ekonomi menengah ke bawah menjadi semakin sulit untuk berobat ke dokter maupun ke rumah sakit. Alternatifnya masyarakat akan memilih obat bebas yang lebih murah dibandingkan ke rumah sakit ataupun dokter. Hal tersebut terkendala karena masalah biaya yang mahal. Biaya yang harus dikeluarkan tidak seimbang dengan penghasilan yang diterima oleh masyarakat tersebut.

Dari alasan di atas penulis akan menjabarkan pernyataan-pernyataan tersebut. Biaya pengobatan yang mahal dikarenakan pelayanan di rumah sakit pemerintah dan rumah sakit swasta saling bersaing dari segi peralatannya. Dari peralatan yang canggih tersebut biaya akan dibebankan oleh pasien. Banyak pula masyarakat yang mengeluhkan untuk berobat di puskesmas karena dokter yang seharusnya memeriksa tidak datang, dan hanya dilayani oleh asisten dokter yang ada di puskesmas. Masyarakat yang tempat tinggalnya jauh dari tempat pengobatan juga akan malas untuk berobat ke puskesmas atau rumah sakit. Terkadang masyarakat akan melanjutkan pengobatan ke dokter apabila sakitnya sudah semakin parah.

Melakukan pengobatan diri sendiri juga merupakan salah satu upaya masyarakat dalam mengatasi masalah kesehatannya secara dini. Semakin berhasil pengobatan diri sendiri dilakukan, akan makin berkurang beban pusat- pusat pelayanan kesehatan yang ada baik di tingkat dasar atau di tingkat rujukan. Dengan mengetahui maksud penggunaan obat oleh masyarakat, apakah untuk menjaga kesehatan dan dapat pula untuk menyembuhkan sakit.

Bila digunakan secara benar, obat bebas seharusnya bisa sangat membantu masyarakat dalam pengobatan sendiri secara aman dan efektif. Namun sayangnya, sering kali dijumpai bahwa pengobatan sendiri menjadi sangat boros karena mengkonsumsi obat-obat yang tidak dibutuhkan, atau malah bisa berbahaya misalnya karena penggunaan yang tidak sesuai dengan aturan pakai. Bagaimanapun obat bebas mempunyai efek samping, sehingga pemakaiannya pun harus sesuai dengan indikasi, lama pemakaian yang benar, disertai dengan pengetahuan pengguna tentang resiko efek samping dan kontraindisinya menurut Suryawati (1997) dalam http://mfi.farmasi.ugm.ac.id/files/ news/5._bu_susi.pdf (diakses tanggal 18 April 2009,1.49PM).

Ketersediaan jumlah tenaga medis dengan jumlah penduduk relatif kurang seimbang, hal ini mendorong untuk melakukan pengobatan sendiri. Obatobatan tersebut dapat diperoleh seperti di warung dan toko obat akan semakin memberi peluang masyarakat Kabupaten Sleman untuk melakukan pengobatan sendiri.

Berdasarkan penelitian yang dilakukan Supardi dan Notosiswoyo (2005) dalam http://mfi.farmasi.ugm.ac.id/files/ news/5.bu susi.pdf (diakses tanggal 18 April 2009,1.49PM), pengetahuan pe- 
ngobatan sendiri umumnya masih rendah dankesadaran masyarakat untuk membaca label pada kemasan obat juga masih kecil. Sumber informasi utama untuk melakukan pengobatan sendiri umumnya berasal dari media massa.Menurut Suryawati (1997) dalam http://mfi.farmasi.ugm.ac.id/ files/news/5.bu susi.pdf (diakses tanggal 18 April 2009, 1.49PM), informasi dari pabrik obat ada yang kurang mendidik masyarakat, ada yang kurang benar.

Semua obat memiliki efek samping walaupun tidak seketika, namun akan kelihatan perlahan-lahan. Sekarang banyak media yang memberitahukan korbankorban yang mengkonsumsi obat-obatan sembarangan mengalami efek yang tidak baik. Seperti diberitakan ada seseorang yang mengalami kulit melepuh setelah mengkonsumsi obat- obatan yang tidak dari resep dokter. Hal tersebut dikarenakan tubuh tidak kuat menerima obat dengan dosis yang dikonsumsi. Sehingga seluruh badan melepuh dan seperti terbakar.

Inilah yang terjadi di dalam masyarakat sekarang ini. Masyarakat hanya berobat dengan sesuai dengan tingkat ekonomi yang ada pada masing-masing individu. Kebanyakan dari masyarakat tidak membaca atau memahami anjuran dari obat-obatan tersebut. Sedangkan penjual hanya ingin mengeruk keuntungan yang sebesar-besarnya tanpa memberikan informasi yang harus disampaikan. Agar masyarakat mengerti dari khasiat ataupun efek samping yang ditimbulkan dari obatobatan tersebut setelah dikonsumsi.

Beberapa kasus yang terjadi dalam masyarakat yang belum memahami informasi yang ada dalam kemasan obat bebas, antara lain: 1) Kasus keracunan obat di Medan, Seorang wanita praktek kerja lapangan (PKL) di Diskes Medan, Minggu (7/9) sekira pukul $21.30 \mathrm{WIB}$, dilarikan ke RSU Pirngadi Medan. Pasalnya, korban yang diketahui bernama Leni Marlina (21) mengalami keracunan obat pereda sakit perut yang sudah kadaluarsa (http:// yokowebs.com/node/438).

2) Kasus keracunan obat sakit kepala di Ngawi. Astuti, warga Ngawi harus tergolek di rumah sakit dengan kondisi sekujur tubuh melepuh seperti habis terbakar. Diagnosa medis menyebutkan dia keracunan obat yang dikonsumsinya ketika mengeluhkan sakit kepala. Kondisinya sangat mengenaskan. Sekujur tubuhnya melepuh seperti bekas terbakar. Menurut pihak rumah sakit, kemungkinan Astuti menderita stephen johnson syndrome atau penyakit yang timbul karena keracunan obat. Astuti meminum obat sakit kepala yang dibelinyasecara bebas darikios didekat rumahnya. Setelah meminum obat sakit kepala yang diduga sudah kadaluwarsa tersebut, Astuti justru merasakan panas sekujur tubuhnya dan kulitnya juga nampak memerah (http:// cybermed.cbn.net.id/cbprtl/Cybermed/ pda/detail. aspx $? \mathrm{x}=$ Health + News\&y $=$ Cybermed\%7C0\%7C0\%7C5\%7C4817).

\section{Metode Penelitian}

Penelitian ini bersifat kualitatif, menurut Van Maanen et al, seperti dikutip H. B. Sutopo (2002:34), dimana peneliti menjelajahi kancah penelitian dan menggunakan sebagian besar waktunya dalam mengumpulkan data secara langsung dan data yang diperoleh benarbenar berdasarkan perspektif dari para subjek yang diteliti dilokasi penelitian. Penelitian ini cenderung mengarahkan kajiannya pada perilaku manusia seharihari dalam keadaannya yang rutin secara apa adanya.

Sementara metode penelitian ini menggunakan metode penelitian deskriptif yaitu penelitian yang hanya memaparkan suatu situasi atau suatu peristiwa secara apa adanya yang terjadi di lokasi penelitian, dimana penulis mengadakan suatu penelitian secara langsung di wilayah Kepuharjo Kecamatan Cangkringan Kabupaten Sleman DIY 
penelitian yang dituju dan penulis juga memutuskan dan menafsirkan data yang ada. Ciri lain dari metode deskriptif menurut Jalaluddin Rahmat (2007:25) ialah menuju titik beratnya pada observasi dan suasana secara alamiah atau naturalisting setting. Penelitian deskriptif mempunyai dua tujuan, yaitu: 1) Untuk mengetahui perkembangan sarana fisik tertentu atau terjadinya suatu aspek tertentu atau terjadinya suatu aspek fenomena sosial tertentu. 2) Untuk mendeskripsikan secara terperinci fenomena sosial tertentu.

Penelitiandeskriptifbiasanyadilakukan tanpa hipotesa yang telah dirumuskan (Rakhmat, 2007: 25), mengatakan bahwa penelitian deskriptif bertujuan untuk: 1) Mengumpulkan informasi aktual secara terperinci yang melukiskan gejala yang ada. 2) Mengidentifikasikan masalah atau memeriksa kondisi dan praktek yang berlaku. 3) Membuat perbandingan atau evaluasi.4)Menentukan apayang dilakukan orang lain dalam menghadapi masalah yang sama, dan belajar dari pengalaman mereka untuk menetapkan rencana dan keputusan pada waktu yang akan datang.

Penelitian deskriptif merupakan penelitian yang bertujuan untuk menggambarkan secara tepat sifat-sifat suatu individu, keadaan atau kelompok tertentu, atau menemukan gejala lain dalam masyarakat mengenai penelitian deskriptif. Penelitian deskriptif memberikan gambaran tentang suatu gejala yang terjadi dalam masyarakat tertentu.

\section{Hasil Penelitian dan Pembahasan}

Motif masyarakat untuk membaca atau memahami informasi yang ada pada kemasan obat yang dijual bebas.

Secara tidak disadari masyarakat sendiri sudah memiliki dorongan atau kemampuan untuk membaca informasi yang ada pada kemasan obat yang dijual bebas terlebih dahulu sebelum mengkonsumsinya. Dorongan tersebut mempunyai alasan yang sangat berarti untuk menjadikan keamanan setelah mengkonsumsi obat. Aman yang dimaksud oleh masyarakat merupakan tindakan yang hati-hati setelah mengkonsumsi obat, agar setelah meminum obat tidak terjadi hal yang tidak diinginkan dengan kata lain fatal. Pertama masyarakat akan membaca masa kedaluarsa obat terlebih dahulu yang tercantum di dalam kemasan obat tersebut. dan sebelum dikonsumsi dibaca terlebih dahulu. Selain masa kedaluarsa, masyarakat juga akan membaca aturan dosis yang seharusnya menjadi panutan sebelum meminum obat. Dilanjutkan dengan membaca anjuran minum sebelum mengkonsumsi obat yang dijual bebas tersebut terlebih dahulu. Hal itu dilakukan agar aman setelah mengkonsumsi obat. Secara tidak langsung pula, masyarakat Kepuharjo telah melek informasi terhadap bahaya obat- obatan yang sering di blow-up oleh televisi. Dengan kesadaran melek informasi tersebut masyarakat desa Kepuharjo sudah peduli terhadap bahaya yang diakibatkan dari salah mengkonsumsi obat.

Masyarakat juga mengatakan takut apabila salah dalam mengkonsumsi obat, dengan maksud salah aturan meminum yang sesuai dengan aturan yang dianjurkan di dalam kemasan obat bebas. Salah satu dari informan juga mengatakan: "nek aturan ngunjukipun kalian tanggal kedaluarsane mesti kulo waos, tha ajreh nek salah kedadean sak baripun ngunjuk obat (kalau aturan minum obat dan tanggal kedaluarsanya selalu saya baca, nanti takut apabila salah kejadian setelah minum obat) (wawancara dengan Bapak Semi 49 tahun, 20 Agustus 2009)“. Dan ada pula informan yang mengatakan: "kulo niki mboten saget maos tulisan, amargi sekolah SD mawon mboten lulus. Nek ajeng ngunjuk obat 
sing kulo tumbas saking warung celak ndalem mesti kulo ngengken anak kulo macake aturan lan tanggal kedaluarsane (saya ini tidak bisa membaca tulisan yang ada pada kemasan obat, karena SD saja tidak lulus. Kalau mau membaca aturan pakai obat yang dibeli dari warung dekat rumah selalu saya menyuruh anak saya membacakan aturan minum dan tanggal kedaluarsanya) (wawancara dengan Bapak Sehono 42 tahun, 21 Agustus 2009)".

Sebagian besar masyarakat desa Kepuharjo yakni 16 dari 25 informan selalu membaca informasi yang ada dalam kemasan obat yang dijual bebas. Ini dilakukannya sebelum mengkonsumsi obat selalu membaca dengan landasan niat dari diri masing- masing. Maksud dari niat ialah dorongan yang tidak disadari dan tidak ada paksaan dari orang lain untuk membacanya. Harapan dari mereka adalah untuk menjadikannya antisipasi dari kesalahan meminum obat. Hal itu dilakukan agar selalu aman dengan maksud tidak salah mengkonsumsi dengan kelebihan dosis minum dan sudah habis masa berlakunya. Misalnya, aturan minum obat seharusnya minum sehari 3 kali akan dilakukan sehari 4 kali ataupun diminum setelah makan akan dilakukan sebelum makan.

Selain membaca aturan minum juga untuk mengetahui masa berlaku obat atau masa kedaluarsa. Apabila obat yang sudah terlambat masa berlakunya dikonsumsi akan mengakibatkan hal yang sangat membahayakan bagi tubuh. Dikarenakan semula yang diinginkan menjadi obat akan menjadi racun bagi tubuh. Informasi yang ada di masyarakat sekarang ini adanya korban salah obat maupun alergi obat yang berakibat badan menjadi melepuh seperti terbakar.

Banyak juga informasi yang diberitakan akhir-akhir ini, bahwa adanya salah konsumsi obat yang mengakibatkan badan menjadi melepuh seperti terbakar.
Dari alasan tersebut, masyarakat menjadi lebih berhati-hati dan lebih peka terhadap informasi yang beredar di masyarakat. Oleh karena itu masyarakat membaca petunjuk minum sebelum mengkonsumsinya. Informan mengatakan bahwa: "sak derange ngunjuk obat mboten kesupen maos tulisan sing wonten wadahe obat riyen, sak liyane maos aturane nggeh maos tanggal kedaluarsane obat pindah. Maose wau sampun apalan saking niate piambak, dados mboten enten sing mekso ngengken maos niku ben kedahe aman sakwise ngunjuk obat (sebelum minum obat tidak lupa membaca tulisan yang ada pada kemasan obat terlebihdahulu, selain membaca aturan juga membaca tanggal kedaluarsa obat sekalian. Membaca petunjuk obat sudah kesadaran dan niat dari diri masing-masing, jadi tidak ada yang memaksa suruh membaca aturan supaya aman saja setelah meminum obat) (wawancara dengan Ibu Tuminah 38 tahun, 22 Agustus 2009)".

Alasan utama masyarakat selalu membaca petunjuk yang ada pada kemasan obat yang dijual bebas ialah supaya aman setelah mengkonsumsi obat tersebut. Khususnya pada masa belaku obat. Adapun petunjuk yang lain misalnya, efek samping obat tersebut kurang diperhatikan. Dikarenakan setiap mengkonsumsi obat selalu aman. Hal tersebut yang menjadikan masyarakat untuk selalu mengulangi obat yang dianggap cocok bagi tubuhnya. Maksud dari masyarakat tersebut karena sudah ada bukti yang nyata setelah mengkonsumsi obat dan berhasil sembuh. Masyarakat lebih percaya dengan hasil yang sudah pernah dialami karena kepercayaan terhadap suatu hal yang sudah melekat di benak masingmasing sangat kuat. Tindakan tersebut akan menjadikan masyarakat untuk berperilaku hafalan terhadap obat yang mereka anggap cocok. Sehingga masyarakat susah untuk berpindah ke produk lain. Dari tabel 1 dapat dilihat bahwa responden yang membaca petunjuk pemakaian obat dengan jawaban 
ya sebanyak 216 orang ( $36 \%$ ) dan yang menjawab tidak sebanyak 384 orang $(64 \%)$.

Dari hasil tersebut dapat disimpulkan bahwa dalam meminum obat responden kebanyakan tidak membaca petunjuk pemakaian obat bebas terlebih dahulu.

Sebagian besar masyarakat desa Kepuharjo hanya membaca petunjuk obat saja, namun tidak dengan informasi yang lainnya yang terdapat dalam kemasan obat yang dijual bebas. Misalnya pada efek samping obat, karena sudah menjadikan kebiasaan masyarakat rasakan setelah minum obat tersebut tidak terjadi hal yang menyimpang. Hal tersebut menjadikan masyarakat kurang memperhatikannya karena beranggapan tidak akan terjadi hal yang memperburuk keadaan sebelumnya. Karena dari pengalaman yang sudah dialami (setelah mengkonsumsi obat) tidak terjadi hal yang memperburuk keadaan melainkan menjadi hal yang diharapkan yaitu menjadikan tubuh menjadi sehat. Ungkapan dari salah satu informan yang sudah peneliti wawancarai: "menawi maos aturane ngunjuk obat kaliyan tanggal kedaluarsane kulo waos terus mboten kesupen, nanging tulisan sak liyane mboten kulo waos amargi sak perlune mawon sing kulo waos, sing penting aturane (apabila membaca aturan minum obat dan tanggal kedaluarsanya saya selalu membaca dan tidak lupa, tapi tulisan yang lain tidak saya baca lagi karena yang saya baca hanya seperlunya yakni aturan minumnya) (wawancara dengan Bapak Sumarno 41 tahun, 24 Agustus 2009)".

Masyarakat biasanya dalam membaca informasi pada kemasan obat yang dijual bebas tidak secara keseluruhan dengan

Tabel 1. Frekuensi Responden Membaca Petunjuk Pemakaian Obat

\begin{tabular}{ccc}
\hline Jawaban & Jumlah & Persentase \\
\hline Ya & 216 & 36,0 \\
Tidak & 384 & 64,0 \\
Total & 600 & 100,0 \\
\hline
\end{tabular}

alasan masyarakat tidak memahami bahasa maupun maksud yang tertulis. Bahasa memang butuh pemahaman yang lebih dalam memaknai ataupun memahaminya. Terkadang bahasa memang sulit untuk menjadikannya tidakan dan maksudya menjadi sepaham. Banyak yang terjadi kalaupun salah maksud dari bahasa akan berbeda tindakannya. Hal ini juga bisa dikarenakan tingkat SDM masyarakat desa Kepuharjo kurang maksimal dalam memahaminya. Masyarakat desa Kepuharjo KabupatenSlemanyangkebanyakantingkat pendidikan masyarakatnya hanya sampai tingkat SD ini menjadikan kendala dalam memahaminya. Masyarakat beranggapan bahwa hanya membaca informasi yang ada pada kemasan obat bebas saja sudah aman apabila sudah mentaati aturannya saja. Bahkan ada sebagian informan yang tidak membaca dan memahami petunjuk yang ada. Hanya berdasarkan cerita keberhasilan orang yang pernah mengkonsumsi obat yang sama. Informan juga ada yang mengatakan: "sampun manut aturane kedah sampun aman, dadi mboten maos tulisane sing liyane (sudah mengikuti aturannya seharusnya sudah aman, jadi tidak membaca tulisan yang lainnya) (wawancara dengan Ibu Slamet 60 tahun, 25 Agustus 2009)".

Hal ini seharusnya menjadi bahan evaluasi bagi pihak farmasi agar menggunakan bahasa dan atau istilah yang mudah dipahami oleh semua kalangan. Penggunaan istilah-istilah farmasi yang terlalu banyak, tentunya akan mempersulit masyarakat untuk memahami informasi yang terdapat dalam kemasan produk obat tersebut, apalagi bila konsumen obat tersebut adalah masyarakat desa Kepuharjo yang sebagian besar penduduknya hanya lulusan SD dan bekerja sebagai petani.

Alasan sebagian besar masyarakat membaca petunjuk pada kemasan obat yang dijual bebas ialah keamanan. Aman menurut masyarakat ialah aman yang bisa 
menjadikan tubuh sehat kembali seperti semula. Yakni keadaan tubuh yang sehat saat sebelum menderita sakit. Sebelum mengkonsumsi obat, masyarakat akan membaca petunjuk dalam obat tersebut guna menjadikan tubuh sehat setelah mengkonsumsiya.

Sehat merupakan hal yang sangat mahal harganya, hal ini pula yang disadari oleh masyarakat Kepuharjo yang meyakini bahwa kesehatan merupakan suatu anugerah yang sangat berharga. Tidak adanya anggaran khusus ketika anggota keluarga mereka sakit, menjadi alasan utama mereka membeli obat yang dijual bebas di warung-warung terdekat. Jadi sangat sedikit masyarakat apabila sakit mendatangi balai kesehatan seperti puskesmas, rumah sakit, dokter atau bidan praktek. Biasanya masyarakat mendatangi balai pengobatan apabila penyakit sudah bertambah parah.

Keadaan tersebut yang menjadi kendala pada masyarakat Kepuharjo yang tingkat ekonominya pada tingkat menengah ke bawah. Informan juga ada yang mengatakan bahwa: "diagem nedho mawon mboten enten, nopo meleh ajeng berobat wonten dokter. Mending tumbas obat wonten warung-warung inkang celak ndalem sami mawon (kalau untuk makan saja sulit, apalagi akan berobat ke dokter mending beli obat yang ada di warung-warung saja sudah cukup dan manjur) (wawancara dengan Bapak X, 27 Agustus 2009)". Hal tersebut yang mendorong masyarakat untuk membeli obat yang dijual secara bebas dalam memberi tindakan apabila sakit. Informan juga mengatakan: "obat sing ditumbas wonten warung sekitar luweh murah dibandingke tumbas wonten apotek, soale biayane tambah awis soale apoteke nggeh tebeh saking dalem (obat yang dibeli di warung dekat rumah lebih murah dibandingkan beli di apotek, karena biayanya lebih mahal disebabkan apoteknya juga jauh dari rumah) (wawancara dengan Ibu Tuminah 38 tahun, 24 Agustus 2009)“.
Sebagian besar masyarakat
memberikan Desa Kepuharjo dalam memberikan
pertolongan pertama apabila sakit ialah dengan mengkonsumsi obat-obatan bebas. Frekuensi meminum obat bebas dapat menggambarkan tingkat keseringan responden dalam meminum obat bebas. Dari hasil tersebut, dapat kita lihat banyaknya responden yang sering meminum obat dapat dilihat pada tabel 2.

Berdasarkan tabel2dapat dilihat bahwa responden yang menjawab sering sebanyak 384 orang $(64 \%)$ dan yang menjawab kadang-kadang sebanyak 216 orang (36\%). Hasil tersebut menunjukan bahwa kebanyakan responden sering meminum obat bebas yaitu sebanyak 384 (64\%), dapat disimpulkan bahwa banyaknya responden yang meminum obat bebas.

Dalam hal ini dapat digambarkan alasan responden dalam meminum obat bebas yang dapat dilihat pada tabel 3 .

Tabel 3 menunjukan bahwa responden yang menjawab mudah didapat dan murah sebayak 300 orang (50\%), sedangkan yang menawab malas ke Dokter sebanyak 156 orang $(26 \%)$, dan yang menjawab tidak ada biaya ke Dokter sebanyak 144 orang (24\%). Dari hasil tersebut dapat disimpulkan bahwa responden dalam meminum obat bebas kebanyakan didasarkan oleh mudah didapat dan murah.

\section{Kemampuan masyarakat untuk memahami informasi yang ada pada kemasan obat yang dijual bebas.}

Seluruh informasi yang ada pada kemasan produk obat yang dijual bebas tidak semuanya dimengerti/dipahami oleh masyarakat terutama masyarakat Kepuharjo. Dikarenakan tingkat pemahaman yang kurang pada individu masing-masing. Semua itu disebabkan oleh tingkat pendidikan yang kurang mendukung untuk bisa dipahami. Di wilayah desa Kepuharjo pendidikan paling tinggi dari responden hanya setingkat SMP. Pemahaman informasi 
Tabel 2. Frekuensi Responden Meminum Obat Bebas

\begin{tabular}{ccc}
\hline Jawaban & Jumlah & Persentase \\
\hline $\begin{array}{c}\text { Sering } \\
\text { Kadang- } \\
\text { kadang }\end{array}$ & 384 & 64,0 \\
Total & 600 & 36,0 \\
\hline
\end{tabular}

yang mereka baca dan mengerti hanyalah sebatas pada petunjuk pemakaian serta tanggal kadaluwarsa. Sementara itu terkadang ditemukan tulisan batas waktu pemakaian atau masa kedaluarsa yang hilang cetakannya sehingga kurang jelas dibaca. Padahal dalam sebuah kemasan produk obat terdapat banyak sekali informasi yang berguna bagi masyarakat, misalnya saja kontraindikasi setelah pemakaian obat, kandungan obat, cara penyimpanan obat, dan lain-lain.

Tabel 4 dapat menggambarkan bahwa tingkat pemahaman responden dalam memahami isi petunjuk pemakaian obat bebas yaitu dengan jawaban paham sebanyak 168 orang (28\%), dengan jawaban sebagian sebanyak 366 orang (56\%), dan yang menjawab tidak paham sebanyak 96 orang (18\%). Dari hasil tersebut dapat disimpulkan bahwa responden dalam memahami isi dalam petunjuk pemakaian obat bebas hanyalah sebagian saja.

Hal ini dikarenakan tingkat pendidikan masyarakat Kepuharjo yang rendah

Tabel 3. Data Alasan Responden Meminum Obat Bebas

\begin{tabular}{ccc}
\hline Jawaban & Jumlah & Persentase \\
\hline $\begin{array}{c}\text { Mudah } \\
\text { didapat }\end{array}$ & 300 & 50,0 \\
dan Murah & & \\
$\begin{array}{c}\text { Malas ke } \\
\text { Dokter } \\
\text { Tak ada } \\
\text { biaya ke } \\
\text { Dokter }\end{array}$ & 156 & 26,0 \\
\hline Total & 600 & 24,0 \\
\hline
\end{tabular}

sehingga tingkat kesadaran untuk mencari informasi sebanyak-banyaknya hanya terpaku pada tingkat kemampuan mereka untuk memahami informasi tersebut saja. Adapun informan yang mengatakan bahwa: "bade pados informasi mawon mboten enten wedal amargi gawean sak ben dintenipun wonten sabin saking enjing dugi sonten. Dugi nggriyo sampun sayah, dados diagem tilem mawon. Menawi sakit tumbas obat wonten warung celak nggriyo ke mawon, trus diagem tilem biasane radi kirangan ngenjing (mau mencari informasi saja tidak ada waktu dikarenakan pekerjaan setiap hari hanya di kebun dari pagi sampai sore. Apabila sudah sampai rumah capek jadi dipakai tidur/ istirahat saja. Kalau sakit beli obat di warung sekitar rumah saja, lalu dipakai tidur biasanya besok pagi sudah mendingan sakitnya) (wawancara dengan Bapak Rujiat 55 tahun, 24 Agustus 2009)“.

Masyarakat sudah memahami aturan konsumsi obat yang dijual bebas yang tercantum pada kemasan obat tersebut. Maksud dari masyarakat dalam memahami aturan konsumsi ialah hanya sebatas aturan minum dan dosisnya saja. Tidak dengan petunjuk yang lainnya seperti efek samping, kontraindikasi, cara penyimpanan dan lain- lain. Hal tersebut dikarenakan masyarakat hanya hafalan saat mengkonsumsi obat pertama kali. Apalagi saat mengkonsumsi obat tersebut sudah cocok dan manjur alias berhasil.

Tabel 4. Data Pemahaman Responden terhadap Isi Petunjuk Pemakaian Obat Bebas

\begin{tabular}{ccc}
\hline Jawaban & Jumlah & Persentase \\
\hline $\begin{array}{c}\text { Paham } \\
\text { Sebagian }\end{array}$ & 368 & 28,0 \\
$\begin{array}{c}\text { Tidak } \\
\text { paham }\end{array}$ & 96 & 18,0 \\
\hline Total & 600 & 100,0 \\
\hline
\end{tabular}


Jadi apabila ada perubahan aturan pakai, efek samping atau petunjuk pemakaian, masyarakat tidak akan mengetahui informasi secara cepat. Oleh karena itu selama masyarakat tidak mencari tahu perkembangan obat tersebut dan produsen tidak gencar mensosialisasikan perubahan hasil produksinya, maka masyarakat tetap tidak akan mengetahui perubahan tersebut. Hal ini menjadi tantangan para produsen obat yang dijual bebas.

Masyarakat pun sudah memahami dan mentaati anjuran konsumsi yang ada pada kemasan obat yang dijual bebas. Dengan maksud dari pemahaman masyarakat tersebut ialah hanya memahami aturan konsumsi atau anjuran minumnya saja. Tindakan ini dilakukan untuk mempercepat proses penyembuhan penyakit dan mempercepat proses pemulihan stamina tubuh. Pada dasarnya melalui petunjuk yang telah tercantum pada kemasan obat yang dijual bebas masyarakat sudah memahami dan mentaati anjuran.

Sebagai contoh, ada informan yang menggunakan obat 2 sampai 3 kali anjuran yang ada dalam kemasan dan belum sembuh masih menunda-nunda untuk pergi ke balai pengobatan. Tetapi tindak lanjut dari proses penyembuhan mereka kurang peduli karena mereka takut dengan biaya yang membengkak yang akan dibayarnya. Adapun kemungkinan penyakit tersebut dibiarkan sampai sembuh dengan sendirinya. Adapun setelah sakitnya bertambah parah dan mendapatkan anjuran dari keluarga, tetangga kiri kanan, mereka baru mau pergi ke balai pengobatan. Hal tersebut memang ada kenyataannya dalam masyarakat dan itupun banyak kejadiannya. Biasanya yang melakukan ini adalah masyarakat yang tingkat pendidikannya SD atau tidak lulus SD. Adapun bagi yang berpendidikan SMP, apabila setelah minum obat belum ada tanda- tanda berkurang atau sembuh segera pergi ke puskesmas terdekat. Bahkan berani bertanya kepada petugas kesehatan yang kebetulan dikenalnya.

Setelah membaca anjuran pemakaian obat masyarakat yang tidak memahami informasi yang telah dibacanya, masyarakat juga tidak bertanya kepada anggota keluarga atau tetangga kiri kanan yang lebih mengerti. Masyarakat menganggap tidak penting, karena masyarakat selalu hafalan dalam memahami informasi obat tersebut. Maksud dari hafalan ialah setiap mengkonsumsi obat masyarakat belum pernah mengalami hal yang fatal melainkan selalu baik. Hal tersebut yang menjadikan masyarakan malas membaca dan menjadikannya suatu kebiasaan. Dikarenakan mereka selalu cocok setelah mengkonsumsi obat dan tidak ada efek samping serta akibat yang didapat setelah mengkonsumsi obat tersebut. Mereka menggap bahwa hal tersebut belum penting dikarenakan mereka tidak akan menggunakannya istilah tersebut.

Biasanya yang tidak dipahami dari masyarakat desa Kepuharjo Kabupaten Sleman adalah nama-nama kandungan yang ada pada obat tersebut. Sebagai contoh, paracetamol, propyphenazone, caffeine dan dexchlorpheniramine maleate (paramex). Istilah, misalnya "kontraindikasi" sebagian besar juga tidak mengerti. Meskipun kata tersebut sudah diserap kedalam bahasa Indonesia. Lebih fatal lagi masyarakat yang hidup di pedesaan terbiasa menggunakan bahasa daerah, dalam hal ini bahasa Jawa. Mereka menjadi susah untuk memahaminya karena mereka tidak terlalu mengerti bahasa Indonesia. Keadaan tersebut menjadikan masyarakat sulit untuk memahami maksud atau tujuan yang diperintahkan. Namun masyarakat desa Kepuharjo Kabupaten Sleman harap dimaklumi karena informasi yang mereka dapat tidak bisa secara cepat, hal tersebut terkendala dengan minimnya tingkat pemahaman masing-masing individunya. 
Pemanfaatan informasi masyarakat terhadap informasi yang ada pada kemasan obat yang dijual bebas.

Masyarakat sudah mentaati aturan informasi yang terdapat pada kemasan obat, hal ini diperkuat dengan adanya anggapan bahwa masyarakat akan mempermudah dan mempercepat proses penyembuhan apabila taat pada aturan. Informan juga mengatakan bahwa: "nggeh nek sampun mantun supoyo saged cepet nyambutdamel malih (apabila sembuh supaya bisa secepatnya melakukan aktivitas kembali seperti semula) (wawancara dengan Bapak Win 27 tahun, 6 September 2009). Masyarakat pun juga takut akan terjadi hal yang sangat fatal apabila tidak mentaati aturan yang tercantum dalam kemasan obat tersebut. Walaupun pemahaman masyarakat hanya terbatas dan terpaku pada aturan pakai atau cara dan dosis pemakaian, sementara masih banyak lagi informasi yang harus dipatuhi. Contoh yang sederhana cara penyimpanan (paramex dalam suhu kamar 25-30 derajat celcius). Contoh yang lain "kontraindikasi" (penderita dengan gangguan fungsi hati, penderita hipersensitif terhadap salah satu komponen) terdapat pada produk paramex. Besar kemungkinan informasi tersebut tidak diikuti oleh masarakat dengan baik. Mereka akan memukul rata bahwa kalau sakit kepala mengkonsumsi obat yang biasa dipakai tanpa memperhatikan kontraindikasi.

Tabel 5 menggambarkan bahwa tingkat ketaatan responden dalam mentaati petunjuk pemakaian obat bebas dengan jawaban taat sebanyak 396 orang $(66 \%)$, tidak taat sebanyak 96 orang (16\%), dan kadang-kadang sebanyak 108 orang (18\%). Dari hasil tersebut dapat disimpulkan bahwa kebanyakan responden mentaati petunjuk pemakaian obat bebas sebanyak 396 orang $(66 \%)$.

Literasi informasi juga berarti melek informasi yang mempunyai maksud seperangkat ketrampilan yang diperlukan untuk mencari, menelusur, menganalisa dan memanfaatkan informasi. Dalam hal ini yang diteliti ialah pemahaman masyarakat tentang informasi yang ada pada kemasan obat yang dijual bebas.

Masyarakat desa Kepuharjo belum sepenuhnya paham terhadap informasi yang ada pada petunjuk obat yang dijual bebas. Sebagian besar masyarakat hanya memahaminya secara hafalan saja. Masyarakatnya sendiri tidak mau mencari dan ingin tahu lagi sesuatu yang baru. Kebanyakan dari mereka sudah merasa cepat puas dengan informasi yang didapat dikarenakan faktor pendidikan yang masih rendah. Tingkat pendidikan yang rendah dan kurangnya informasi dari pergaulan dengan orang lain yang lebih mengerti akan informasi, menjadikan masyarakat cepat puas dengan apa yang mereka dapat.

Masyarakat desa Kepuharjo dalam memahami informasi yang ada pada kemasan obat yang dijual bebas dengan cara melek informasi atau literasi informasi. Kemelekan informasi meliputi kemampuan untuk mengenali kapan informasi dibutuhkan dan untuk menemukan, mengevaluasi, menggunakan secara efektif, dan menyampaikan informasi dalam beragam bentuknya. Pada ke-nyataannya di masyarakat desa Kepuharjo sebagian besar masyarakatnya belum melek informasi terhadap informasi yang ada pada kemasan obat bebas. Dikarenakan masyarakat tidak memahami informasi yang ada pada kemasan obat bebas secara keseluruhan.

Masyarakat sendiri hanya terpatok pada aturan yang mereka pahami masingmasing. Jadi masyarakat tidak bisa berkembang dalam mencari informasi. Mereka hanya hafalan saja dalam menjalankan aktifitas, misalnya membaca aturan minum obat.

Masyarakat tidak mempunyai greget untuk mencari informasi sedalam- 
Tabel 5. Data Frekuensi Responden Meminum Obat Bebas

\begin{tabular}{ccc}
\hline Jawaban & Jumlah & Persentase \\
\hline Taat & 396 & 66,0 \\
Tidak Taat & 96 & 16,0 \\
$\begin{array}{c}\text { Kadang- } \\
\text { kadang }\end{array}$ & 108 & 18,0 \\
\hline Total & 600 & 100,0 \\
\hline
\end{tabular}

dalamnya. Dalam mencari informasi tersebut masyarakat juga tidak maksimal dikarenakan tidak menggunakan alat bantu yang diperlukan saat pencarian informasi berlangsung.

Ilmu penunjang penelitian tentang pemahaman informasi pada masyarakat desa Kepuharjo, peneliti menggunakan komunikasikesehatandalammemperkuat pemikirannya. Masalah yang diteliti bersangkutan dengan kesehatan pada masyarakat. Ilmu pendukung tersebut, adalah komunikasi kesehatan yang bisa menjadikan pendidikan untuk masyarakat agar lebih memperhatikan kesehatannya.

Kehidupan bermasyarakat, komunikasi sangat diperlukan untuk bertukar informasi. Manusia merupakan makhuk sosial yang tidak bisa lepas dari bantuan orang lain. Secara tidak disadari manusia sudah melakukan tindakan komunikasi dalam kehidupan sehariharinya. Hal tersebut manusia selalu melakukannya untuk mempertahankan kehidupannya serta komunikasi dalam masyarakat sangat penting karena dengan adanya komunikasi maka seseorang bisa berhubungan dengan orang lain dan saling bertukar pikiran yang bisa menambah wawasan seseorang dalam menjalani kehidupan sehari-hari.

Masyarakat desa Kepuharjo Kabupaten Sleman dalam hal ini sudah melakukan tindakan komunikasi dalam membeli obat yang dijual bebas di warung-warung sekitar tempat tinggalnya. Mereka sudah berinteraksi sebelum akan mengkonsumsi obat dikarenakan masyarakat membaca aturan minum terlebih dahulu sebelum mengkonsumsinya. Terjadinya proses pengoperasian rangsangan yang berupa lambang (tulisan) dilanjutkan perubahan sikap yang dilakukan setelah membacanya.

Komunikasi kesehatan adalah studi yang mempelajari bagaimana cara menggunakan strategi komunikasi untuk menyebarluaskan informasi kesehatan yang dapat mempengaruhi individu dan komunitas agar mereka dapat membuat keputusan yang tepat berkaitan dengan pengelolaan kesehatan (Liliweri, 2007:46). Pendidikan kesehatan adalah suatu penerapan konsep pendidikan dalam bidang kesehatan di masyarakat. Pendidikan kesehatan merupakan suatu praktik dan konsep pendidikan yang diaplikasikan pada bidang kesehatan Tujuan pendidikan kesehatan adalah mengajarkan orang untuk hidup dalam kondisi yang terbaik, yaitu berusaha keras untuk mencapai tingkat kesehatan yang maksimum. Pendidikan kesehatan ini dipandang sebagai suatu strategi untuk penurunan biaya melalui pencegahan penyakit (di komunitas/masyarakat) dan menghindari pengobatan medis yang mahal dan dengan menurunkan lamanya hari perawatan dan memfasilitasi pemulangan lebih dini (jika di rumah sakit/klinik).

Pendidikan kesehatan merupakan suatu upaya atau kegiatan untuk menciptakan perilaku masyarakat yang kondusif untuk kesehatan. Artinya, pendidikan kesehatan berupaya agar masyarakat menyadari atau mengetahui bagaimana cara memelihara kesehatan mereka, bagaimana menghindari atau mencegah hal-hal yang merugikan kesehatan, kemana harus mencari pengobatan bila sakit, dan sebagainya. 
Kesehatan bukan hanya untuk diketahui atau disadari dan disikapi, melainkan harus dikerjakan/dilaksanakan dalam kehidupan sehari-hari. Hal ini berarti tujuan akhir dari pendidikan kesehatan adalah agar masyarakat dapat mempraktikkan hidup sehat bagi dirinya sendiri dan bagi masyarakat, atau masyarakat dapat berperilaku hidup sehat (health life style).

Pengetahuan kesehatan secara dini dimaksudkan agar masyarakat desa Kepuharjo Kabupaten Sleman mengerti dan paham akan kesehatan. Kesehatan merupakan hal yang sangat penting bagi kehidupan. Masyarakat seharusnya sudah menjadi lebih tahu dengan kesehatan lingkungan sekitar di masyarakat. Secara praktis, komunikasi kesehatan memberikan kontribusi bagi promosi kesehatan, mencegah penyakit dalam suatu wilayah.

Di wilayah Kepuharjo sendiri masyarakatnya juga sudah diberi penyuluhan tentang bahaya obat serta cara pemakaian obat bebas, seperti yang dikatakan Bapak Arif Wibawa, SKM selaku Kepala Puskesmas Cangkringan:

"Penyuluhan yang diberikan kepada masyarakat tentang bahaya dari obat bebas sudah menjadi program dari pemerintah. Program dari pemerintah tersebut turun ke tangan Kepala Puskesmas Induk kecamatan, lalu dari Puskesmas di lakukan oleh Posyandu maupun Rakor yang memberikan penyuluhan kepada masyarakat langsung dalam 1 bulan 1 kali. Selain kepada masyarakat, juga kepada siswa SMKN 1 Cangkringan yang dijadikan program dalam pemberian penyuluhannya. Setiap bulan penyuluhan akan selalu berbeda dan mengikuti dari program Dinas Kesehatan. Masyarakat desa Kepuharjo sangat responsif apabila ada penyuluhan, namun masyarakat juga banyak yang mengabaikan disaat pelaksanaannya seperti kurang cermat dalam memahami informasi obat bebas. Jadi masyarakat tidak melaksanakan sesuai dengan penyuluhan yang disampaikan. Misalnya, apabila akan mengkonsumsi obat bebas tidak dibaca seluruhnya dan apabila menderita sakit tidak secepatnya pergi ke balai pengobatan melainkan tetap bekerja untuk mendapatkan penghasilan. Mereka biasanya akan memberikan pertolongan pertama dengan meminum obat bebas yang dibeli di warung sekitar. Setelah sakitnya semakin parah barulah pergi ke balai pengobatan. Kebanyakan dari masyarakat akan pergi ke balai pengobatan disaat sore hari. Alasan masyarakat ialah apabila pagi hari digunakan untuk bekerja agar mendapat penghasilan. Kepala Puskesmas Cangkringan juga membenarkan bahwa masyarakat di desa Kepuharjo lebih memilih obat bebas dalam melakukan pengobatan pertama dikarenakan biayanya lebih murah. Masyarakat desa Kepuharjo sebagian besar tergolong dalam tingkat ekonomi menengah ke bawah dan berpendidikan rendah yakni sebagian besar hanya lulusan SMP. Produsen obat bebas tidak bisa bekerjasama dengan pelayanan kesehatan dari pemerintah untuk mempromosikan kepada masyarakat. Kemudian cara yang digunakan oleh produsen obat bebas dengan cara beriklan (Wawancara dengan Kepala Puskesmas Cangkringan, 14 Desember 2009)“. Pendidikan kesehatan masyarakat desa Kepuharjo belum sepenuhnya dijalankan oleh masyarakat. Mereka hanya mendukung programprogram pendidikan kesehatannya saja, namun kegiatannya belum sepenuhnya dijalankan. Kegiatan penyuluhan yang dilakukan setiap 1 bulan 1 kali memang masyarakat sangat antusias dalam memberikan respons. Respons tersebut hanyalah sesaat saat penyuluhan dilakukan. Setelah penyuluhan selesai 
pendidikan kesehatan yang diberikan tidak dijalankan oleh masyarakat. Artinya masyarakat belum mempunyai kesadaran untuk hidup sehat dan taat pada pendidikan kesehatan.

Obat bebas dan obat bebas terbatas merupakan kategori obat yang dapat digunakan masyarakat dalam upaya pengobatan sendiri. Kriteria suatu obat dapat dimasukkan ke dalam kategori ini antara lain adalah bahwa obat yang bersangkutan telah terbukti secara ilmiah menunjukkan manfaat klinis, sangat diperlukan untuk menanggulangi kesakitan yang banyak dijumpai di masyarakat, relatif aman, dan penggunaannya oleh masyarakat dapat dipantau oleh badan yang berwenang mengawasi.

Dari ketentuan di atas, dapat dimengerti bahwa sebenarnya kebijakan untuk menggolongkan obat tertentu menjadi obat bebas dan bebas terbatas adalah untuk meningkatkan ketersediaan akan obat-obat bagi masyarakat, dalam upaya untuk melakukan pengobatan sendiri. Bila digunakan secara benar, obat-obat ini seharusnya bisa sangat membantu masyarakat dalam pengobatan sendiri secara aman dan efektif. Namun sayangnya, seringkali dijumpai bahwa pengobatan sendiri menjadi sangat boros karena mengkonsumsi obat-obat yang sebenarnya tidak dibutuhkan, atau malah bisa berbahaya misalnya karena penggunaan yang tidak sesuai aturan pakai. Bagaimanapun, obat bebas dan bebas terbatas bukan berarti bebas efek samping, sehingga pemakaiannyapun harus sesuai dengan indikasi, dosis, lama pemakaian yang benar, disertai dengan pengetahuan pengguna tentang risiko efek samping dan kontraindikasinya. Untuk melakukan pengobatan sendiri secara aman dan efektif, diperlukan pengetahuan dan ketrampilan memilih obat.
Masyarakat desa Kepuharjo Cangkringan Sleman memilih obat bebas apabila memberikan pertolongan pertama apabila sakit. Biasanya masyarakat membeli obat bebas di warung sekitar tempat tinggalnya. Masyarakat lebih memilih obat bebas dengan alasan murah dan cepat mendapatkannya. Obat yang sering dikonsumsi sebagian besar masyarakat desa Kepuharjo Cangkringan Sleman ialah procold, puyer bintang toedjoe dan paramex.

Salah satu komponen kebutuhan utama dengan demikian adalah informasi. Informasi yang ideal adalah informasi yang objektif, lengkap, dan tidak menyesatkan. Sayangnya, informasi yang ideal tersebut masih jarang dijumpai dalam kehidupan sehari-hari. Informasi yang paling banyak dijumpai di masyarakat sehari-hari adalah informasi yang berasal dari industri farmasi, yang bersifat komersiil. Bentuk utamanya adalah iklan. Bila arus informasi yang non komersiil dan komersil imbang, dan masyarakat mampu menelaah informasi secara kritis, maka sebenarnya masalah informasi mungkin tidak begitu mengkhawatirkan seperti sekarang ini.

Untuk meningkatkan kerasionalan pengobatan sendiri, maka di samping upaya-upaya untuk meningkatkan pengetahuan dan ketrampilan masyarakat dalam memilih obat dan menganalisis secara kritis informasi obat, juga diperlukan upaya-upaya untuk mengendalikan informasi komersil. Tujuannya agar informasi yang disediakan benar, dalam arti dapat dipertanggung-jawabkan secara ilmiah, tidak menyembunyikan risiko pengobatan, serta tidak menyesatkan atau mengarahkan pengguna kepada persepsi yang keliru yang kemudian dapat mengakibatkan penggunaan obat secara keliru. 
Informasi harus lengkap, artinya tidak menyembunyikan kekurangankekurangan obatnya, yang dapat berupa efek samping, kontraindikasi, dan peringatan-peringatan yang menyertai penggunaan obatnya. Selain itu nama senyawa bahan aktif tidak boleh disembunyikan dengan alasan apapun. Penyebutan nama bahan aktif harus dengan istilah yang telah diterima secara luas, yaitu nama generik atau nama INN (International Non-Proprietary Name). Penyebutan dengan nama istilah kimiawi atau memberikan nama paten terhadap bahan aktif tidak diperbolehkan. Kekurangtahuan konsumen terhadap nama-nama bahan aktif obat tidak boleh dimanfaatkan untuk menarik keuntungan. Kekurangtahuan masyarakat ini jangan sampai menjadi alasan untuk tidak memberikan informasi mengenai nama bahan aktif.

Masyarakat desa Kepuharjo, tentunya tidak berbeda jauh dengan masyarakat lainnya yang hidup di pedesaan bahwa apabila menderita sakit lebih memilih obat-obat yang dijual bebas di pasaran sebagai pertolongan pertama. Obat-obat yang mereka perlukan sudah tersedia di warung-warung yang ada di sekitarnya, sehingga minat pergi ke balai pengobatan berkurang. Mereka menganggap obat-obat yang ada di warung- warung sudah cukup untuk mengobati penyakitnya. Selain itu obatobat tersebut mudah ditemukan, murah, cepat mendapatkannya, dan paling penting dianggap sangat cocok. Dalam hal ini peran media sangat mendukung, baik media cetak maupun media elektronik.

Televisi memang merupakan media massa paling hebat dibanding media massa lainnya. Televisi tidak mengenal batas. Televisi melipatgandakan efek media dalam menjalankan tugas memberikan informasi, pendidikan, hiburan, dan bimbingan. Hal ini pula yang disadari oleh masyarakat Kepuharjo dimana menurut mereka televisi mempunyai imajinasi tersendiri. Imaji televisi memang dikenal keampuhannya. Sebagian besar anggota masyarakat memandang televisi sebagai salah satu sumber pencarian informasi.

Bahasa televisi memiliki keragaman unsur-unsur semiotika, yakni gambar, suara, dan aspek-aspek non verbal. Semuanya harus dibangun secara harmonis dan memikat di dalam kemasan siaran yang bersifat audio visual. Kelebihan televisi, selain menjadi tempat orang menerima kebenaran dan akurasi informasi, ialah menjadi penyampai nilai-nilai atraktif kepada sejumlah besar orang secara serentak dan luas melalui hitungan bisnis media yang menguntungkan.

Motif masyarakat desa Kepuharjo dalam membaca dan memahami informasi yang ada pada kemasan obat yang dijual bebas ialah untuk menjadikan rasa aman setelah mengkonsumsi obat tersebut. Rasa aman yang masyarakat inginkan ialah aman yang tidak akan terjadi hal yang fatal setelah mengkonsumsi obat. Dengan alasan tersebut masyarakat akan membaca terlebih dahulu aturan minum sebelum mengkonsumsi obat. Masayarakat desa Kepuharjo takut apabila salah dalam mengkonsumsi obat, oleh sebab itu masyarakat akan selalu membaca terlebih dahulu sebelum mengkonsumsi obat. Adapun masyarakat yang tidak bisa membaca sebelum mengkonsumsi obat akan mencari bantuan kepada anggota keluarga maupun orang lain untuk meminta bantuan membacakan anjuran minum dan masa kedaluarsa obat tersebut. Namun masyarakat dalam membaca anjuran konsumsi obat hanya sebatas petunjuk dan masa berlakunya saja. Masyarakat menganggap bahwa apabila sudah membaca petunjuk dan 
masa kedaluarsa sudah cukup dan sesudah menjadikan aman setelah meminum. Hal tersebut membuat masyarakat tidak membaca informasi lagi yang terdapat dalam kemasan obat yang dijual bebas tersebut. Misalnya saja efek samping, kontraindikasi dan lainlain. Masyarakat hanya hafalan dalam memahami efek sampingnya yakni akan mengantuk setelah mengkonsumsi obat. Kebanyakan dari masyarakat juga tidak akan membaca efek samping secara keseluruhan.

Alasan masyarakat tidak membaca secara keseluruhan ialah tingkat kesulitan dalam pemahaman untuk memahami bahasa maupun tulisan yang ada pada kemasan obat yang dijual bebas tersebut. Dengan alasan tersebut menjadikan masyarakat untuk malas membaca dikarenakan apabila membaca juga tidak paham pula maksud yang disampaikan.

Obat yang masyarakat dapatkan ialah obat yang masuk kategori obat bebas yakni obat yang dijual di pasaran tanpa resep dokter. Masyarakat desa Kepuharjo memilih pengobatan sendiri dengan alasan untuk pertolongan pertama, murah, mudah didapatkan, dan terjangkau harganya. Dari alasan masyarakat tersebut, keinginan untuk pergi ke balai pengobatan setelah menindaklanjuti apabila meminum obat yang dibeli di warung-warung tidak manjur. Masyarakat menganggap bahwa pergi ke balai pengobatan sangat mahal dikarenakan biaya. Tingkat ekonomi masyarakat desa Kepuharjo Kabupaten Sleman sebagian besar masyarakatnya pada tingkat eonomi menengah ke bawah. Masyarakat yang sebagian besar hanya berkebun dan beternak. Mereka hanya memperoleh informasi hanya terpaku tingkat kemampuan masingmasing yakni kemampuan individu.

Pemahaman masyarakat dalam mencari informasi hanya sebatas aturan minumdandosisobatsaja, tanpamembaca petunjuk lain seperti efek samping, kontra indikasi, cara penyimpanan dan lain-lain. Sedapat mungkin masyarakat kelas bawah yang pendidikanya sangat minim dapat mengikuti perkembangan informasi obat andalannya. Hal ini dimaksudkan agar apabila ada perubahan aturan pakai atau dosis masyarakat dengan cepat memperoleh informasi tersebut. Untuk itu, ini merupakan tantangan serta pekerjaan bagi para produsen obat bebas untuk memberikan sosialisasi perubahan hasil produknya kepada para konsumen mereka. Dengan adanya sosialisasi tersebut maka imbas dari semua itu bukan hanya untuk para konsumen obat bebas, selain masyarakat mendapatkan informasi yang lengkap tentang obat tersebut baik itu aturan pakai, dosis, kontra indikasi, dan lain-lain, tetapi kepercayaan masyarakat akan obat tersebut bertambah. Hal ini berpengaruh juga pada penjualan produk para produsen obat. Namun untuk sekarang hal itu belum sepenuhnya tercapai. Itu dikarenakan kebiasaan masyarakat yang cenderung hafalan dalam memahami informasi obat bebas tersebut. Inilah yang menjadikan masyarakat malas membaca dan sudah menjadi kebiasaan yang buruk. Biasanya yang tidak dipahami oleh masyarakat pada umumnya adalah nama kandungan yang terdapat pada obat tersebut. Tentu pula berpatok pada tingkat kemampuan pemahaman masingmasing individunya.

Masyarakat akan menindak lanjuti anjuran yang ada pada kemasan produk obat bebas apabila setelah mengkonsumsi obat tersebut tidak kunjung ada perubahan guna mengantisipasi sakit yang semakin parah. Sehingga pada saat mendatangi balai pengobatan sudah dalam keadaan akut karena asal meminum obat. Kesehatan memang belum sepenuhnya diperhatikan secar 
khusus oleh sebagian besar masyarakat desa Kepuharjo Kabupaten Sleman. Masyarakat mudah percaya apabila sudah ada hasil yang didapat saat pertama kali mengkonsumsi obat yang tersebut. Hal itulah yang menjadikan masyarakat menganggap informasi obat tersebut tidak lagi penting karena sudah berfikir kalau obat tersebut manjur.

Manfaat informasi yang ada pada kemasan obat yang dijual bebas bagi masyarakat desa Kepuharjo Kabupaten Sleman setelah membacanya ialah menjadikan badan sehat. Dengan maksud bahwa setelah mengkonsumsi obat yang dijual bebas dan memperhatikan aturan minumnya yang sesuai pada kemasan. Masyarakat juga bisa mengamati dan merasakan kondisi tubuhnya sendiri setelah mengkonsumsi obat. Keterangan tersebut juga ada pada petunjuk yang ada pada kemasan obat dengan kata lain efek samping. Namun sebagian masyarakat jarang yang membacanya. Aturan dan petunjuk pemakaian obat yang terdapat dalam kemasannaya merupakan suatu informasi yang diberikan produsen obat kepada konsumen. Informasi yang masyarakat baca di kemasan merupakan suatu ilmu yang akan dijadikan pedoman untuk pengobatan selanjutnya. Dari informasi yang didapat masyarakat dalam kemasan produk obat, masyarakat bisa mengamati dan akan menindak lanjuti kalaupun tidak ada perkembangan setelah meminum obat.

\section{Simpulan}

Berdasarkan hasil pembahasan tentang "Literasi Informasi yang Ada dalam Kemasan Produk Obat Bebas" terhadap (Studi Dskriptif Pemahaman Informasi pada Masyarakat di Wilayah Kepuharjo Cangkringan Sleman) pada bab terdahulu, maka dapat disimpulkan bahwa masyarakat desa Kepuharjo Cangkringan Sleman belum sepenuhnya memahami informasi yang ada pada kemasan obat bebas, hal tersebut diperkuat dengan:

Motif masyarakat untuk membaca atau memahami informasi yang ada pada kemasan obat yang dijual bebas. Masyarakat menjadikannya supaya aman apabila sudah membaca masa kedaluarsa maupun aturan minum obat. Aman yang masyarakat cari ialah untuk tidak terjadi hal yang tidak diinginkan setelah meminum obat.

Kemampuan masyarakat untuk memahami informasi yang ada pada kemasan obat yang dijual bebas. Masyarakat hanya sebatas memahami masa berlaku dan aturan pakai obat. Dalam memahami informasi yang lain masyarakat belum bisa dikarenakan tingkat pendidikan yang kurang. Jadi masyarakat hanya membaca informasi yang dibutuhkan pada saat akan meminum saja. Masyarakat tidak akan membaca informasi yang lainnya secara keseluruhan.

Pemanfaatan informasi masyarakat terhadap informasi yang ada pada kemasan yang dijual bebas. Masyarakat akan menjalankannya sesuai dengan aturan apabila mengkonsumsi obat. Harapan masyarakat mentaatinya ialah supaya sesuai dengan harapan yang diinginkan yakni cepat sembuh. Alasan yang lain ialah menjadikan informasi ataupun ilmu untuk menjadikan pengetahuan berikutnya apabila akan mengkonsumsi obat.

Berdasarkan hasil penelitian, masyarakat yang hanya membaca informasi secara hafalan akan tidak mengetahui apabila ada perubahan dalam informasi yang ada pada kemasan obat yang dijual bebas. Produsen sebaiknya mensosialisakan yang lebih mengena dan lebih bisa dipahami masyarakat secara menyeluruh dengan memberi tulisan yang lebih tebal. Produsen sebaiknya menonjolkan informasi paling penting yang terkait langsung dengan obat 
secara mudah dipahami oleh konsumen. Kebanyakan salah satu petunjuk itu berbunyi demikaian "apabila sakit berlanjut hubungi dokter" (petunjuk dalam) sebaiknya selain petunjuk tersebut, produsen juga mncantumkan berapa kali maksimal penggunaan obat dan disarankan harus periksa ke dokter agar masyarakat semakin jelas. Sebab selama ini belum ada produsen yang mencantumkan informasi tersebut.

Sebagian besar masyarakat dalam membaca informasi yang ada dalam kemasan produk obat bebas tidak seluruhnya dibaca. Kalaupun masyarakat membaca hanya sebagian saja. Olehkarena itu masyarakat lebih detail dan mau dalam membaca dan memahami informasi mengenai aturan, anjuran maupun masa berlaku obat yang ada pada kemasan obat yang dijual bebas.

Peneliti juga memberikan saran dan masukan kepada peneliti yang akan datang sebaiknya melakukan penelitian yang baru dengan berbagai acuan penelitian lainnya, selain deskriptif, misalnya melakukan analisis isi terhadap program-programnya, semiotika logo, dan sebagainya sehingga penelitan menjadi lebih bervariasi. Penelitian yang bervariasi dapat menambah wawasan dan pengetahuan bagi para pembaca.

\section{Daftar Pustaka}

H.B, Sutopo. (2002). Metodologi Penelitian Kualitatif. Surakarta: UNS Press.

Liliweri, Alo.(1997). Komunikasi Antarpribadi. Bandung: PT. Citra Aditya Bakti.

Effendy, Onong Uchjana. (2003). Ilmu Komunikasi Teori dan Praktek. Cetakan kesembilanbelas. Bandung: PT Remaja Rosdakarya.
Rahmat, Jalaluddin. (2007). Metode Penelitian Komunikasi. Bandung: Rosda Karya.

Supratiknya, A. (1995). Komunikasi Antarpribadi: Tinjauan Psikologis. Yogyakarta: Kanisius.

\section{Internet}

(Depkes:http://depkes.go.id/index. php ? option $=$ news $\&$ task $=$ viewarticle $\& \operatorname{sid}=1522$ \& itemid $=2: 3 / 14 / 2007$ ) (diakses tanggal 19 April 2009, 1. 01 PM).

http://mfi.farmasi.ugm.ac.id/files / news/5._bu_susi.pdf (diakses tanggal 18 April 2009,1.49PM).

(http:/ / yokowebs.com/node/438) (diakses tanggal 16 Juli 2009, 2. 45 AM).

(http://www.sumeks.co.id/index. php?option=com_content \& task $=$ view \& id $=3102 \&$ Itemid $=44$ ) (diakses tanggal 16 Juli 2009, 2.41 AM).

(http:/ / cybermed.cbn.net.id/cbprtl/ Cybermed/pda/detail. aspx? $\mathrm{x}=$ Health + News \& y = Cybermed \% 7C 0\% 7C0\% 7C5\% 7C4817). (diakses tanggal 16 Juli 2009, 2.47 AM).

( h t t p : / / fazhaji.wordpress. com/2009/08/19/cara- makan minum-obat-yang-baik-danbenar/) (diakses tanggal 14 Desember 2009, 12. 24 AM).

http:/ / www.library.unisa.edu.au / about/papers/-clever.pdf. (diakses tanggal 4 Mei 2009, 10. 27 PM). 